\title{
Improved Theoretical Conversion Efficiency of a Dual Junction GalnP/Si Mechanically Stacked Photovoltaic Cell
}

\author{
Debashish Pal \\ M.Tech., Department of Electronics and Communication Engineering, Institute of Engineering and Management, \\ Kolkata, India \\ pal.debashish@gmail.com
}

\begin{abstract}
Dual junction tandem solar cells can utilize the solar spectrum photons with a broader range of energies as compared to the conventional single junction solar cells; thereby demonstrating higher conversion efficiency. This paper deals with the numerical modeling of a dual junction GalnP/Si based multijunction tandem photovoltaic cell. The semi empirical modeling approach was used for simulation which produced a theoretical one sun conversion efficiency of over $30 \%$ for the proposed four terminal configuration.
\end{abstract}

Keywords - ARC, Open Circuit Voltage, PC1D, Short Circuit Current, Tandem cell, TCO

\section{INTRODUCTION}

Multijunction solar cells are more sensitive to solar spectrum than single junction solar cells [1-2]. Single junction silicon based solar cells have reached their peak conversion efficiency limits in the field of photovoltaics [3]. However, stacking a silicon solar cell with a higher bandgap material solar cell enables theoretical one sun conversion efficiencies exceeding the $30 \%$ limit. A larger bandgap material on the top absorbs photons with higher frequencies ensuring reduction in the efficiency losses associated with the thermalisation process. The materials most suited for the development of high efficiency multijunction solar cells are the III-V compound semiconductors, where the lattice matching condition can be managed. Additionally, silicon as a substrate has the advantages of being relatively cheap and abundant as well as having good radiation resistance [4-5].

Mostly tandem cells use series connection of subcells resulting in two terminal devices. Boundary condition associated with two terminal configuration requires that the current in both the subcells remains equal. For the power output to reach the maximum under these conditions exact current matching is required. This can be achieved by adjusting the thickness and doping concentration of different layers. The power deliverable to an external load is strongly.

72 limited by the efficiency of the top cell. In a four terminal configuration however, the operating points of the subcells can be controlled independently ensuring maximum transfer of power. In a four terminal configuration, the maximum power of each subcell is independent of one another, therefore, the electrical matching remains optimal. Four terminal mechanically stacked GalnP/Si cells are connected by an adhesive which allows higher degree of flexibility in terms of circuit wiring [6-8].

\section{MODELING}

In this paper, semi empirical modeling was used to demonstrate the performance of $\mathrm{GalnP} / \mathrm{Si}$ dual junction solar cell. The GalnP and silicon sub-cells were simulated independently each at its own maximum power point. Unlike the monolithic multijunction devices there is no need for the current matching between the sub-cells here as it is a four terminal configuration.

The integration of the GalnP cell with the $\mathrm{Si}$ cell reduces the intrinsic limitation associated with the standalone $\mathrm{Si}$ cell. Conversion of the short wavelength radiation associated with the solar spectrum can be achieved by the GalnP cell while the conversion of the longer wavelength radiation is taken care of by the Si cell.

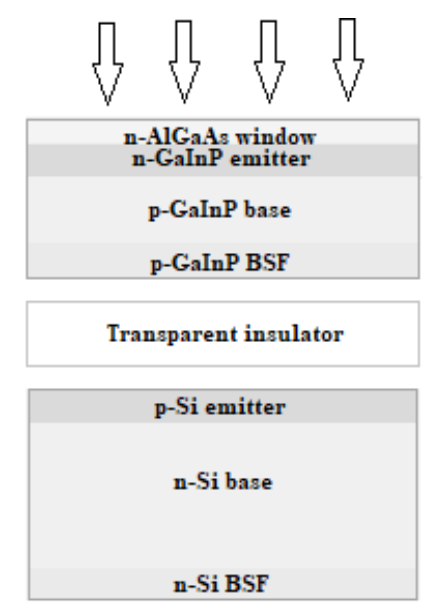

Fig .1. Schematic diagram of the four-terminal photovoltaic cell 
Fig. 1 shows the schematic diagram of the dual junction tandem solar cell which comprises a GalnP based top cell of thickness $1.7 \mu \mathrm{m}$ and a siliconbased bottom cell having thickness of $230 \mu \mathrm{m}$. The top cell has an AIGaAs based wide bandgap $(2.1 \mathrm{eV})$ window material having variable thickness. Each of the subcells has uniformly doped emitter and base layers of variable thickness and doping concentrations. To generate an electric field barrier for the minority carriers, the top and the bottom subcells have back surface field (BSF) layers of adjustable doping concentration and thickness. The electric field avoids the possibility of surface recombination. However, these adjustments are made keeping the total thickness of the top and the bottom cells constant at $1.7 \mu \mathrm{m}$ and $230 \mu \mathrm{m}$, respectively [9]. In practice, to avoid the inherent optical losses associated with the mechanically stacked solar cells, electrically insulating and optically transparent adhesives are used to bond the cells.

For the sake of simplicity, the structure used for electrical characterization does not incorporate any defects at the interface and the surface or losses related to the tunnel junction (for the two terminal configuration) and the insulation. The operating temperature was chosen to be $25^{\circ} \mathrm{C}$ with a device area of $1 \mathrm{~cm}^{2}$. The optimization of the sub-cells was performed under AM1.5G one sun illumination condition having an intensity of $0.1 \mathrm{~W} / \mathrm{cm}^{2}$. The modeling and simulations were performed using PC1D simulation software [10], which is a computer program used for modeling crystalline semiconductor devices with emphasis on photovoltaic devices and is used as a simulation tool to understand the operation of solar cells yielding reliable results. The parameters used in the simulation are taken from reference [9]. The GalnP top cell has a ZnS anti-reflection coating on the front side and the Si bottom cell has a TCO coating on the front face (not shown in fig. 1). The $\mathrm{ZnS}$ and the TCO coatings on the front side of the cells have been optimised using simulations. The modelling considers a $1.7 \mu \mathrm{m}$ thick GalnP cell and a $230 \mu \mathrm{m}$ thick Si cell with constant light trapping.

\section{RESULTS AND DISCUSSION}

Historically, AIGaAs/Si dual junction solar cell has achieved 1 -sun efficiency exceeding $21 \%$ by the epitaxial growth technique [11]. III-V/Si multi-junction solar cells were also demonstrated to achieve efficiencies of over $25 \%$ and $30 \%$ under 1 -sun and 112-suns by means of direct wafer bonding [12-13]. Mechanically stacked GalnP/InGaAs/Si based solar cell has been reported to achieve efficiency of over $27 \%$ under 1 -sun [14].

Unlike the AllnP window layer, S. Essig, M. A. Steiner, C. Allebé, J.F. Geisz, B. Paviet-Salomon, S. Ward, A. Descoeudres, V. LaSalvia, L. Barraud, N. Badel, A. Faes, J. Levrat, M. Despeisse, C. Ballif, P. Stradins, D.L. Young, "Realization of GalnP/Si dualjunction solar cells with $29.8 \%$ one-sun efficiency", an $\mathrm{AlGaAs}$ window layer having a dielectric constant of 10.63 is chosen over the GalnP top cell having a lattice mismatch of only $0.03 \%$. The window layer has a uniform n-type doping concentration of $1 \times 10^{17}$ atoms $/ \mathrm{cm}^{3}$. The thickness of the window layer is varied to find the optimum value of efficiency.

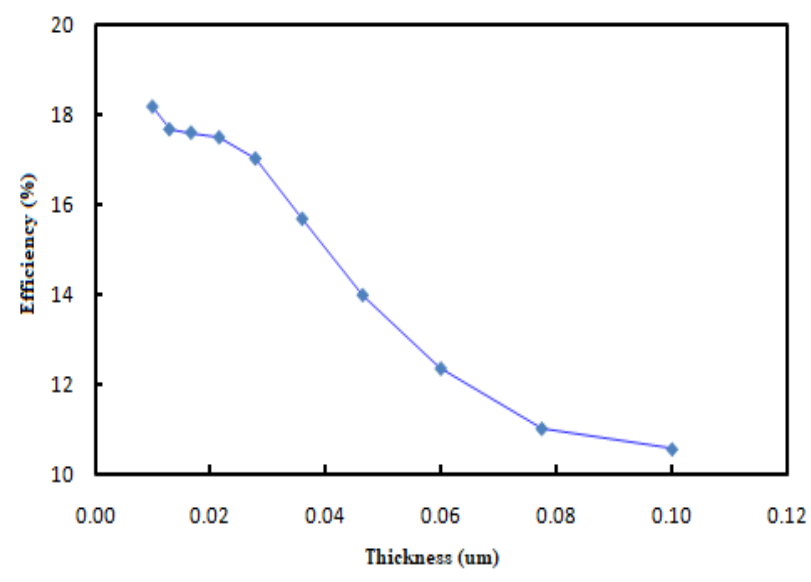

Fig .2. Window layer thickness vs. efficiency

The result of the simulation (Fig. 2) indicates that the efficiency is at a maximum value of $18.17 \%$ when the thickness of the window layer is at $0.01 \mu \mathrm{m}$.

A study to determine the influence of the thickness of the ZnS anti-reflection coating on the fraction of photon current absorbed and reflected for the GalnP cell was performed. The incident light passes through the ZnS anti-reflective coating (refractive index=3.805-2.252) and the AIGaAs window layer (refractive index=1.368-3.124) before reaching the GalnP substrate. This structure causes a refractive index mismatch which makes the ZnS ARC layer less reflective. A similar examination was conducted for the bottom cell having a TCO layer (refractive index=2.447-1.953) on top of the Si substrate. For different values of the $\mathrm{ZnS}$ and TCO layer thickness, the fractions of photon current absorbed and reflected are summarised in Table I. 
Table I. Influence of the ZnS and ITO Layers on the Percentage of Photons Absorbed and Reflected by the GalnP Cell and the Si Cell, Respectively

\begin{tabular}{|c|c|c|c|c|c|}
\hline Cell & \multicolumn{2}{|c|}{$\begin{array}{c}\text { Thickness } \\
(\mu \mathrm{m})\end{array}$} & $\begin{array}{c}\text { Fractional } \\
\text { Photon } \\
\text { Current } \\
\text { Absorbed } \\
(\%)\end{array}$ & $\begin{array}{c}\text { Fractional } \\
\text { Photon } \\
\text { Current } \\
\text { Reflected } \\
(\%)\end{array}$ & $\begin{array}{c}\text { Efficiency } \\
(\%)\end{array}$ \\
\hline \multirow{2}{*}{ GalnP } & \multirow{2}{*}{$\begin{array}{c}\text { ZnS } \\
\text { layer }\end{array}$} & 10 & 68.7 & 28.6 & 13.7 \\
\cline { 3 - 6 } & & 50 & 87.5 & 9.4 & 18.2 \\
\cline { 3 - 6 } & & 100 & 70.8 & 25.8 & 14.3 \\
\cline { 3 - 6 } & 150 & 76.8 & 19.5 & 16.1 \\
\hline \multirow{2}{*}{$\mathrm{Si}$} & \multirow{2}{*}{$\begin{array}{c}\text { ITO } \\
\text { layer }\end{array}$} & 10 & 72.9 & 0.5 & 13.3 \\
\cline { 3 - 6 } & & 50 & 69.7 & 10.6 & 12.0 \\
\cline { 3 - 6 } & & 100 & 62.3 & 15.9 & 11.1 \\
\cline { 3 - 6 } & 150 & 65.6 & 12.5 & 11.5 \\
\hline
\end{tabular}

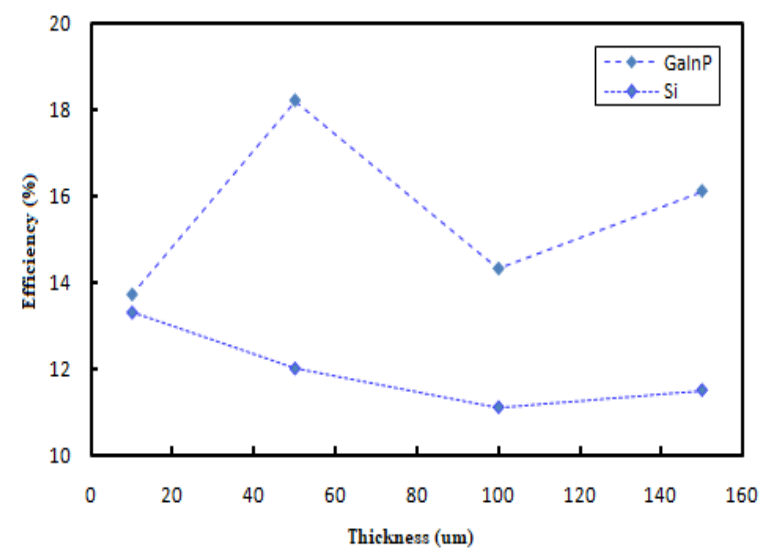

Fig .3. Dependence of efficiency on the thickness of ZnS ARC and ITO layer

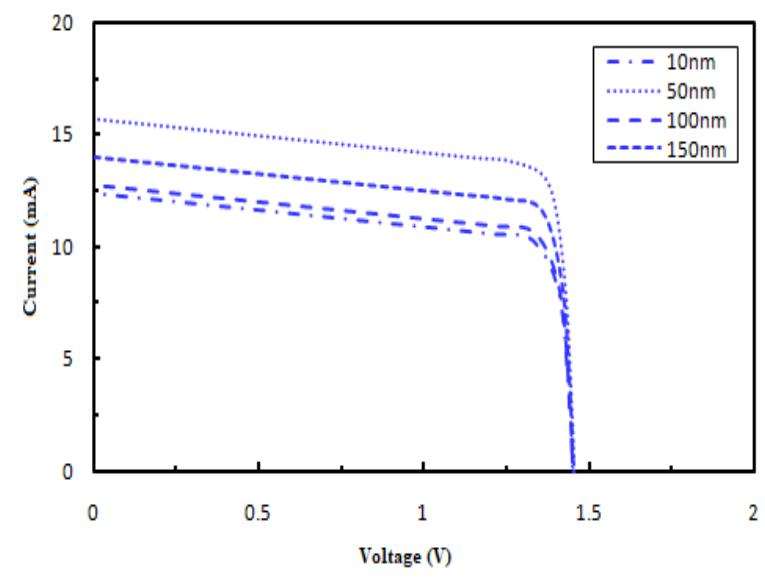

Fig .4. Current-Voltage characteristics of GalnP cell for different thickness of ZnS anti-reflective coating

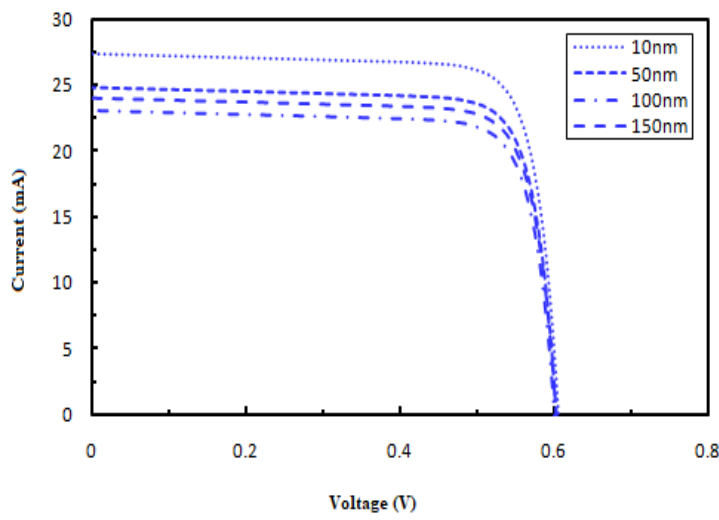

Fig .5. Current-Voltage characteristics of Si cell for different thickness of ITO layer

Fig. 3,4 and 5 show that there is a strong dependence of the solar cell I-V characteristics on the thickness of the $\mathrm{ZnS}$ anti-reflection coating and the ITO layer. It can be observed from the I-V characteristics that for the GalnP cell the efficiency is maximum with a ZnS ARC coating thickness of $50 \mathrm{~nm}$. Also, the efficiency is maximum for an ITO layer thickness of $10 \mathrm{~nm}$ for the Si cell. These results are in direct agreement with the data presented in Table I, which establishes that the percentage of photons absorbed by the base layer is greatest for the stated thicknesses.

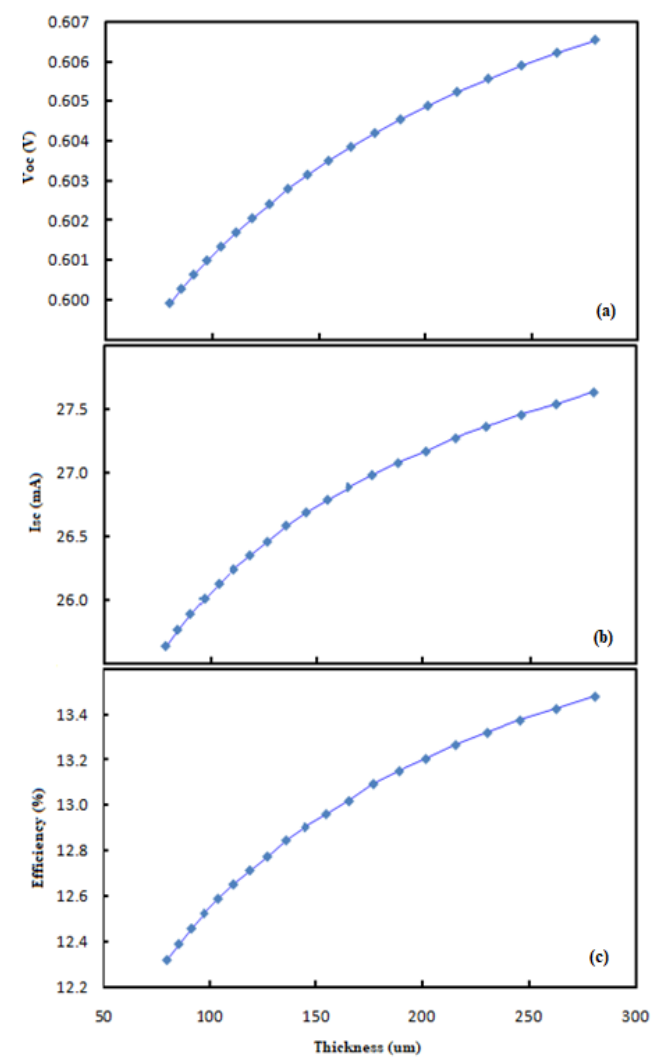

Fig .6. Influence of thickness of the Si bottom cell on (a) VOC (b) ISC (c) Efficiency 
Fig. 6 shows the dependence of the open circuit voltage, short circuit current and the efficiency on the thickness of the Si cell. As the thickness of the cell increases, the interaction of the incident photons with the cell improves. Thus, for greater cell thickness the incident photons generate a bigger number of electron-hole pairs, which in turn increases the overall photocurrent in the cell improving the efficiency.

Table II. Optimised Parameters of the Top and the Bottom Cell Used for the Final Design

\begin{tabular}{|l|l|l|}
\hline Parameters & Si Cell & $\begin{array}{l}\text { GalnP } \\
\text { Cell }\end{array}$ \\
\hline Thickness $(\mu \mathrm{m})$ & 230 & 1.7 \\
\hline Dielectric Constant & 11.9 & 11.8 \\
\hline Bandgap $(\mathrm{eV})$ & 1.12 & 1.86 \\
\hline Emitter Thickness $(\mu \mathrm{m})$ & 10 & 0.1 \\
\hline $\begin{array}{l}\text { Emitter Doping Concentration } \\
\left(/ \mathrm{cm}^{3}\right)\end{array}$ & $\begin{array}{l}1 \times 10^{17} \\
(\mathrm{p} \text {-type })\end{array}$ & $\begin{array}{l}5 \times 10^{17} \\
(\mathrm{n} \text {-type })\end{array}$ \\
\hline Base Thickness $(\mu \mathrm{m})$ & 215 & 1.49 \\
\hline $\begin{array}{l}\text { Base Doping Concentration } \\
\left(/ \mathrm{cm}^{3}\right)\end{array}$ & $\begin{array}{l}1 \times 10^{16} \\
(\mathrm{n} \text {-type) }\end{array}$ & $\begin{array}{l}1 \times 10^{16} \\
(\mathrm{p}-\text { type })\end{array}$ \\
\hline BSF Thickness $(\mu \mathrm{m})$ & 5 & 0.1 \\
\hline $\begin{array}{l}\text { BSF Doping Concentration } \\
\left(/ \mathrm{cm}^{3}\right)\end{array}$ & $\begin{array}{l}1 \times 10^{17} \\
(\mathrm{n} \text {-type) }\end{array}$ & $\begin{array}{l}4 \times 10^{18} \\
(\mathrm{p} \text {-type })\end{array}$ \\
\hline $\begin{array}{l}\text { Front Surface Recombination } \\
\text { Velocity }(\mathrm{cm} / \mathrm{s})\end{array}$ & 10000 & 10000 \\
\hline $\begin{array}{l}\text { Rear Surface Recombination } \\
\text { Velocity }(\mathrm{cm} / \mathrm{s})\end{array}$ & 10000 & 10000 \\
\hline
\end{tabular}

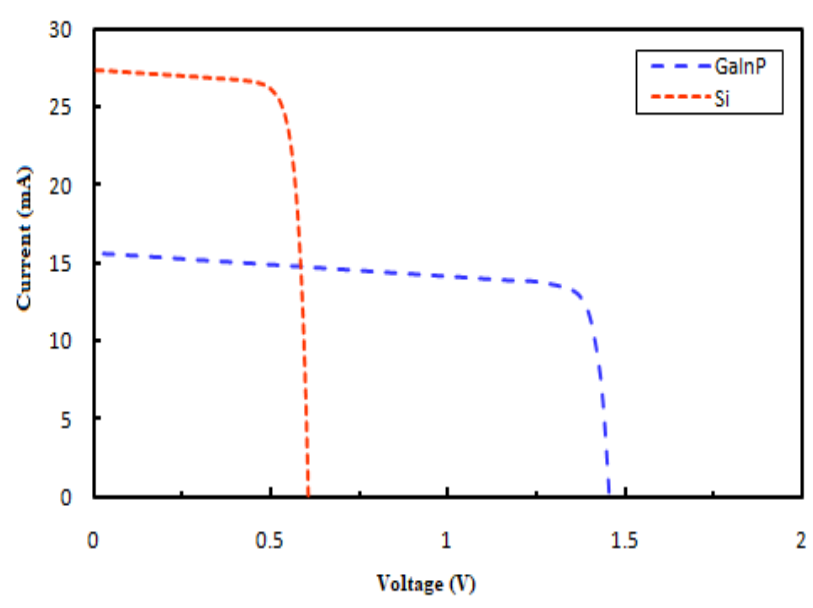

Fig .7. Current-Voltage characteristics of the optimised fourterminal photovoltaic cell

The theoretical model of the solar cell described in this investigation exceeds the experimental efficiency value of $25.6 \%$ [15] of a single junction Si solar cell. The efficiency of the tandem cell described in this paper is also close to the record one-sun efficiency of $31.1 \%$ [16] which was achieved with a monolithic
GalnP/GaAs dual junction structure. The tandem cell theoretical efficiency of $31.5 \%$ for the structure under investigation in this paper is in close agreement with the practical efficiency of $29.8 \pm 0.6 \%$ obtained in S. Essig, M. A. Steiner, C. Allebé, J.F. Geisz, B. PavietSalomon, S. Ward, A. Descoeudres, V. LaSalvia, L. Barraud, N. Badel, A. Faes, J. Levrat, M. Despeisse, C. Ballif, P. Stradins, D.L. Young, "Realization of GalnP/Si dual-junction solar cells with $29.8 \%$ one-sun efficiency". An in-house efficiency of $31.5 \%$ was reported for a mechanically stacked interdigitated back contact dual junction solar cell. The Si bottom cell efficiency recorded therein was $12.5 \%$, while the GalnP top cell demonstrated single junction efficiency of $19.1 \%$ [17]. Furthermore, it was shown that dual junction III-V/Si mechanically stacked and independently operated solar cell could reach cumulative one sun efficiencies of over $32 \%$ [18].

Table III: Summary of the Results

\begin{tabular}{|c|c|c|c|}
\hline Cell & $V_{\text {oc }}(\mathrm{V})$ & $\mathrm{I}_{\mathrm{sc}}(\mathrm{mA})$ & Efficiency (\%) \\
\hline $\mathrm{Si}$ & 0.6056 & 27.4 & 13.3 \\
\hline GalnP & 1.455 & 15.7 & 18.2 \\
\hline Tandem & 2.0606 & 15.7 & 31.5 \\
\hline
\end{tabular}

\section{IV.CONCLUSION}

Studies performed on the mechanically stacked GalnP/Si based dual-junction solar cell structure achieved an accumulative one-sun efficiency of $31.5 \%$. It can be observed that the overall efficiency of the solar cell is largely dependent on the efficiency of the top cell. The overall efficiency of the tandem cell is highly dependent on the thickness of the window layer, anti-reflection coating, ITO layer and the substrate thickness. Greater efficiencies can be achieved by increasing the open circuit voltage of the Si bottom cell and increasing the short circuit current of the GalnP top cell.

\section{REFERENCES}

[1] S.R. Kurtz, J.M. Olson and P. Faine. "The difference between standard and average efficiencies of multijunction compared with single-junction concentrator cells," Sol. Cells, vol. 30, no. 1-4, 1991, pp. 501-513,.

[2] P. Faine, S.R. Kurtz, C. Riordan and J.M. Olson. "The influence of spectral solar irradiance variations on the performance of selected single- 
junction and multijunction solar cells," Sol. Cells, vol. 31, no. 3, 1991, pp. 259-278.

[3] D.D. Smith, P. Cousins, S. Westerberg, R. De Jesus-Tabajonda, G. Aniero and Y.-C. Shen. "Toward the Practical Limits of Silicon Solar Cells." IEEE Journal of Photovoltaics, vol. 4, no. 6, pp. $1465-1469,2014$.

[4] M. Yang, T. Soga, T. Jimbo and M. Umeno. "High efficiency monolithic GaAs/Si tandem solar cells grown by MOCVD," in Proc of Twenty Fourth IEEE Photovoltaic Specialists Conference, vol. 2, 1994, pp. 1847-1850.

[5] J.F. Geisz, Olson, D.J. Friedman, K.M. Jones, R.C. Reedyand M.J. Romero. "Lattice-matched GaNPAs-on-Silicon tandem solar cells," in Proc of Thirty-first IEEE Photovoltaic Specialists Conference, 2005, pp. 695- 698.

[6] S. Essig, S. Ward, M.A. Steiner, D.J. Friedman, J.F. Geisz, P. Stradinsand D.L. Young. "Progress towards a $30 \%$ efficient GalnP/Si tandem solar cell," Energy Procedia vol. 77, 2015, pp. 464-469.

[7] J. Yang, Z. Peng, D. Cheong and R.N. Kleiman. "III-V on silicon multi-junction solar cell with $25 \%$ 1-Sun efficiency via direct metal interconnect and areal current matching," in Proc. of the $27^{\text {th }}$ European Photovoltaic Solar Energy Conference and Exhibition, Frankfurt, Germany, 2012, pp. $160-163$.

[8] K.M. Gee and G.F. Virshup. "A 30\%-efficient $\mathrm{GaAs} /$ silicon mechanically stacked, multijunction concentrator solar cell," Conference records of the 20th IEEE Photovoltaic Specialists Conference, Las Vegas, USA, 1988, pp. 754758.

[9] S. Essig, M. A. Steiner, C. Allebé, J. F. Geisz, B. Paviet-Salomon,

S. Ward, A. Descoeudres, V. LaSalvia, L. Barraud, N. Badel, A. Faes,

J. Levrat, M. Despeisse, C. Ballif, P. Stradinsand

D. L. Young, "Realization of GalnP/Si Dualjunction Solar Cells with $29.8 \%$ One-sun Efficiency." IEEE Journal of Photovoltaics, vol. 6, issue: 4, pp. 1-8, July 2016.
[10] PC1D, version 5.9, School of Photovoltaic and Renewable Energy Engineering at the University of New South Wales, Australia, 2008.

[11] T. Soga, K. Baskar, T. Kato, T. Jimboand M. Umeno. "MOCVD Growth of high Efficiency Current-matched A1GaAs/Si Tandem Solar Cell." Journal of Crystal Growth, vol. 174, pp. 579-584, 1997.

[12] S. Essig, J. Benick, M. Schachtner, A. Wekkeli, M. Hermle and F. Dimroth. "Wafer-bonded GalnP/GaAs//Si Solar Cells With 30\% Efficiency Under Concentrated Sunlight." IEEE Journal of Photovoltaics, vol. 5, no. 3, pp. 977-981, 2015.

[13] K. Tanabe, K. Watanabe and Y. Arakawa. "III$\mathrm{V} / \mathrm{Si}$ hybrid photonic devices by direct fusion bonding," Scientific Reports, vol. 2, no. 349, pp. 1-6, 2012.

[14] J. Yang, Z. Peng, D. Cheong and R. Kleiman. "III-V on silicon multi-junction solar cell with $25 \%$ 1 -sun efficiency via direct metal interconnect and areal current matching," Proc of the 27th European Photovoltaic Solar Energy Conference and Exhibition, Frankfurt, Germany, 2012, pp. 160-163.

[15] K. Masuko, M. Shigematsu, T. Hashiguchi, D. Fujishima, M. Kai, N. Yoshimura, T. Yamaguchi, Y. Ichihashi, T. Yamanishi, T. Takahama M. Taguchi, E. Maruyama and S. Okamoto. "Achievement of More than 25\% Conversion Efficiency with Crystalline Silicon Heterojunction Solar Cell," IEEE Journal of Photovoltaics, vol. 4, pp. 1433-1435, 2014.

[16] M. Steiner et al., "article title," Proc of 41st IEEE PVSC (write full name), Tampa, USA, 2013, pp. 1429.

[17] M. Riennacker, M. Schnabel, E. Warren, A. Merkle, H.Schulte-Huxel, T.R. Klein, M.F.A.M. van Hest, M.A. Steiner, J. Geisz, S.K.-Schroder, R. Niepelt, J. Schmidt, R. Brendel, P. Stradins, A. Tamboli and R. Peibst. "Mechanically stacked dual-junction and triple-junction III-V/Si-IBC cells with efficiencies of $31.5 \%$ and $35.4 \%$." in Proc of 33rd European PV Solar Energy Conference and Exhibition, 2017, pp1-4. 
[18] S. Essig, C. Allebe, T. Remo, J.F. Geisz, M.A. Steiner, K. Horowitz, L. Barraud, J.S. Ward, M. Schnabel, A. Descoeudres, D.L. Young, M. Woodhouse, M. Despeisse, C. Ballif and A.
Tamboli. "Raising the one-sun conversion efficiency of III-V/Si solar cells to $32.8 \%$ for two junctions and $35.9 \%$ for three junctions," Nature Energy, vol. 2, 2017, pp. 17-44. 